\title{
Ning Wang, Making a Market Economy; Yan Sun, Corruption and Market in Contemporary China
}

\section{Gilles Guiheux}

\section{(2) OpenEdition}

12 Journals

Édition électronique

URL : http://journals.openedition.org/chinaperspectives/2733

DOI : 10.4000/chinaperspectives. 2733

ISSN : 1996-4617

Éditeur

Centre d'étude français sur la Chine contemporaine

\section{Édition imprimée}

Date de publication : 15 décembre 2007

ISSN : 2070-3449

Référence électronique

Gilles Guiheux, "Ning Wang, Making a Market Economy; Yan Sun, Corruption and Market in Contemporary China », China Perspectives [En ligne], 2007/4 | 2007, mis en ligne le 09 avril 2008, consulté le 23 septembre 2020. URL : http://journals.openedition.org/chinaperspectives/2733 ; DOI : https://doi.org/10.4000/chinaperspectives.2733

Ce document a été généré automatiquement le 23 septembre 2020.

(C) All rights reserved 


\title{
Ning Wang, Making a Market Economy; Yan Sun, Corruption and Market in Contemporary China
}

\author{
Gilles Guiheux
}

1 These two works shed light on the conditions under which, in the course of the last 25 years, the command economy has been dismantled and gradually replaced by a market system in China . Yan Sun, a professor of political science, is interested in corruption from a double perspective, both at the macro and the micro level. Ning Wang, a neoinstitutionalist economist, asks how, thanks to the reforms, a region (Jingzhou, south of Hubei ) has been converted to pisciculture.

2 Corruption is a crucial question, since it threatens both social stability - it has direct consequences for the distribution of wealth - and the legitimacy of political power - it provokes popular discontent. Yan Sun's work sets out a broad panorama of corrupt practices that have been employed since 1978, understood in the (restricted) sense to which the Chinese judicial apparatus extends, that is to say "the abuses of power committed by officials of the State and of the Party to the benefit of private interests." The author takes a look at corrupt people (Who are they? To what level of the hierarchy do they belong?), at the funds in question (What are the amounts involved? Are they related to the commercialisation of services?), andat the structural elements that make possible and indeed encourage these practices. Forming part of the literature that is dedicated to the transition of former communist countries and seeks to find out if corruption is the price to be paid for the switch to a market economy, Yan Sun studies how the reforms (and the change to a market economy) have made corruption possible, but also how, in return, corruption has influenced the reforms. She shows how and why liberalisation has been accompanied by corruption and what the consequences of that are.

3 The research and analysis are based on an important body of Chinese sources, a dozen casebooks that compile corruption cases, published between 1989 and 2003 by the disciplinary committees (both local and central in Beijing ) of the Communist Party, 
and judicial editions. These volumes describe the corrupt practices that have been punished by the Chinese judicial system throughout the country; they deal with both the local and central apparatus of the party and of the state, both those responsible for state-owned enterprises and the executives of private companies. The presentation is built up on systematic comparisons. Yan Sun analyses the dynamics of corruption in the different contexts of the reform process. In terms of the timeframe, she distinguishes the years 1978-1992, when planning remained important, from the period that followed, after Deng Xiaoping's southern tour, which marks the definitive erosion of the command economy in favour of the market. Before 1992, corruption is of less importance; the sums at stake are smaller and the cadres involved are located at a lower administrative level. In terms of geography, Yan Sun compares the rich coastal provinces with the poorer inland provinces. The analysis confirms that liberalisation and the reforms facilitate corruption. The author similarly distinguishes between corruption that gives rise to a reciprocal exchange of goods or services ("transaction corruption ") and corruption where the goods or services move in a single direction (embezzlement of funds, fraudulent appropriation, etc.). Finally, Yan Sun compares the case of China with that of Russia . If in China the state has not fallen into the hands of a mafia, she explains, it is because it is not as weakened as its Russian counterpart was. In the Chinese case, the party and state cadres were able to take advantage of the reforms; in Russia 's case, the absence of opportunities of this type led officials to oppose reform. Certainly, the capacity of the Chinese state to control its agents under the effects of decentralisation and of the transformation of its functions has diminished, but it remains powerful in its institutional (continuity of the regime) and political (autonomy of the political elite) dimensions. Furthermore, when the command economy was split open in China, dynamic non-state economic actors (the village and township enterprises) took up the baton, while in Russia the vacuum left by the retreat of the state was filled by a new oligarchy and organised crime.

The presentation is methodical, relying on accounts of both well-known corruption cases (such as Chen Xitong, the mayor of Beijing dismissed in 1995, and Lai Changxing, the head of the Yuanhua Group in Xiamen, who became China 's most wanted man in the autumn of 1999) and those less well known, which reveal the reality of the dynamics and of the mechanisms in play in a variety of contexts. What will be noted from the work's conclusions is that corruption is largely a product of the post-Mao reforms, made possible by the opportunities born from a progressive change to a market economy ("dual track" price system, new regulations, reform of state-owned enterprises, etc.); the gradual retreat of the state subsequently increased the opportunities for corruption. Corruption is thus, according to Yan Sun, extensively a consequence of the economic reforms ${ }^{1}$. Secondly, with regard to the effects of corruption on the reforms, the author highlights a clear difference between the two periods before and after 1992. During the first period, corruption helped facilitate the reforms and played a positive role in accelerating the dismantling of the command economy. After 1992, corruption created major obstacles to the deepening of the reforms. In other words, contrary to what a certain neo-liberal theory maintains, the growing liberalisation of the economy is accompanied by growth in corruption.

It is perhaps regrettable that the author has not taken the trouble to set the corrupt practices in China under reform against the yardstick of Chinese history and thus put them into greater per- spective or give more weight to their disclosure. Is it not also the case that corruption is now exposed and denounced more in the press? That is 
worth explaining. Finally, forward-looking reflection is undoubtedly lacking. But it remains the case that this is a methodical and rigorous work that is useful thanks to its ambition to be exhaustive.

6 For his part, Ning Wang takes a look at the conditions under which a particular region changed to specialised production as a result of the reforms. His brief work (145 pages) constitutes a monograph on the region around Changhu Lake $(30 \mathrm{~km}$ long and $18 \mathrm{~km}$ wide) to the south of Hubei , the author's own place of origin. He studies the process by which the transition to a market economy has transformed this portion of the Chinese countryside in a micro-analysis of based on 30 or so interviews with peasants and local heads conducted in 1997 and 1998.

7 The southern part of Hubei in the vicinity of Jingzhou is a region of natural lakes, rivers, and canals. Before 1978, the peasants fished strictly for subsistence purposes. Only a single state farm, set up on the banks of Changhu Lake, was dedicated to this activity in a professional fashion that qualified it as a fish "producer." The introduction of contracts under the household responsibility system at the end of the 1970s did not initiate any genuine rupture, as the peasants were still not free to choose their own means of production, which they carried out on land acquired under lease. When the peasants were authorised to convert their agricultural lands into fish farms, they did it on a massive scale to supply the urban markets that were developing rapidly. It was only then that fish production became their principal activity, no longer on Changhu Lake, but within the framework of farms, the majority of which were operated by several households affiliated in partnerships. Thanks to the reforms, the capture of fish, a marginal activity for subsistence purposes, became the area's dominant productive activity with commercial aims and oriented on supplying the Jingzhou market.

8 Ning Wang's goal is to study how, within an agricultural framework, a market economy became established. To do this, he mobilises the acquired knowledge of neoinstitutionalist economics (the work moreover features a preface by one of this branch's principal figures, Ronald Coase, Nobel laureate for economics in 1991). He is interested in the institutions, understood as the whole body of rules and standards that provide the framework for and regulate economic behaviour, or, to put it another way, the rules of the game of pisciculture. The author thus directs his attention at three institutions. He first asks questions about the conditions under which there emerged markets (for fish), non-existent in the decades in the 1970s and 1980s. He then brings his thoughts to bear on the consequences of the new individual property rights. Finally, he looks at the fish farms considered as productive organisations.

9 On this Chinese terrain, Ning Wang seeks to confirm some of the conclusions of neoinstitutionalist economics. Thus the emergence of a hierarchy of markets - small wholesale markets close to the producers, medium-sized markets and, at the top, the main market in Jingzhou - is accompanied by the development of an intermediation activity, the raison d'être of which is to minimise the transaction costs for producers and consumers, something that confirms Ronald Coase's definition of markets. Ning Wang notes that if the development of the commercial activity, once the prohibitions had been lifted, was somewhat spontaneous, the definition of property rights still requires state intervention. But he also shows that this in itself is not sufficient. The consolidation of the new system of rights has only been made possible by the transformation of social norms; the observance of new formal rules thus depends on 
the transformation of uses and associated values. In particular, the peasants only respected the property rights of the state farm over the fish farming resources of Changhu Lake the day that they themselves became proprietors of fish farms. Considered until then as customary and normal, individual (and illegal) fishing has since that time been an activity that is socially disapproved of and condemned. Ning Wang underlines here the ideological dimension of the social change: it is not enough to transform the institutions; even more necessary is the social actors' evolving perception of their interests. New legal norms are only observed from the time that social norms are transformed.

On the question of property rights, the transition in China is often associated with privatisation. But Ning Wang shows that not only have the collective forms of property not been weakened, they have actually been reinforced. Thanks to the reforms, the state farm operating on Changhu Lake has seen its interests consolidated. What's more, fish farms operated by individuals are rare. Because the management of a farm requires a large workforce, and economies of scale make a large farm more profitable, the majority of the farms bring together several families in a partnership. ${ }^{2}$ The preferred style of organisation is thus an association of individuals in new collective forms.

One drawback in this work may be the sometimes inadequate linkage between theoretical developments and the actual Chinese terrain, a shortcoming of numerous publications produced from Anglo-Saxon doctoral theses; its major interest lies in its narrative and monographic dimension and in the restoration of the strategies and points of view of the actors (in particular pp. 72 to 92). In the chapter devoted to property rights, Ning Wang relates in particular the conflicts between the collective enterprise operating on Changhu Lake and the individual fishermen (before the establishment of fish farms and while commercial demand was growing). The intensification of the fishing carried out on an individual basis culminated in the virtual disappearance of the fish stock. When the state farm tried to enforce observance of its legal rights in the face of the "wild" (because illegal) fishing, the confrontations became violent. To protect their material interests and resist the application of the law, the peasants organised themselves into "illegal fishing gangs" ( dixia buyu dui). There was thus a sharpening of the conflict between the legal state property rights and existing social norms. Appeasement arrived with the development of the fish farms and the decline of fishing by individuals in the lake. Once the peasants themselves became proprietors, they became concerned about their own rights and respected those of the state farm. To understand the conditions leading to the emergence of a market economy, it is thus not sufficient to pay attention only to the reforms set in motion by the state; it is also necessary, as these two works usefully remind us, to take a look at the modalities under which the social actors take on the new arrangements or resist them. 


\section{NOTES}

1. Yan Sun thus disputes the validity of the arguments of those such as Lü Xiaobo ( Cadre and Corruption: The Institutional Involution of the Chinese Communist Party, Stanford, Stanford University Press, 2000) who associate corruption with the legacy of the Maoist political system.

2. See on a similar subject: Susanne Brandtstädter, "Money Plucked from the Sky: Shrimp Farming, Entrepreneurship and the Circulation of Know-How in a Fujian Village" , Taiwan Journal of Anthropology, 2 (1), 2004, p. 41-67. Susanne Brandtstädter takes a look at the emergence of rural entrepreneurs and places the emphasis on the distribution of know-how within the village community. 